\title{
Application of $\mathrm{NH}_{3} / \mathrm{CO}_{2}$ refrigerant cooling system in a cold storage project
}

\author{
Dao Zhou, Kang Wang * \\ CCCC-FHDI ENGINEERING CO., LTD., Guangzhou, 510290, China
}

\begin{abstract}
Taking a project's integrated logistics dry port as an example, the advantages and disadvantages of several commonly used refrigerants and their systems are compared and analyzed from safety, environmental protection and energy saving. The technical principles of the NH3 / CO2 refrigerant cooling system are briefly described, and the introduction is also introduced. The refrigeration system selection, equipment configuration and automatic control system scheme of the project refrigerator were provided, which can provide a reference for the selection of the refrigeration scheme of the cold chain project in the future.
\end{abstract}

Keywords. $\mathrm{NH}_{3}, \mathrm{CO}_{2}$, refrigeration, cold chain, environmental protection, safety.

\section{Preface}

With the advancement of science and technology, the development of refrigeration technology, and people's needs for a better life, more and more cold chain projects have emerged at the historic moment. Cold chain logistics has become a necessity of today's life and is closely related to people's lives. Cold chain engineering has become a popular fashion. It refers to all aspects of the production, transportation, storage, and sales of frozen and refrigerated foods until the consumer consumes them. They are always controlled in a low temperature environment that meets the requirements to reduce food losses and ensure A systematic engineering of food quality. The Guilin Suqiao Dry Port Phase-I project (hereinafter referred to as the "Project") described in this article is just such a cold chain project. The design of the refrigeration system of this project follows many factors such as energy efficiency, safety and environmental protection. $\mathrm{CO}_{2}$ refrigerant cooling system, in order to achieve high-quality use effect and corresponding balance.

\section{Project Overview}

The total land area of this project is 185413.8 square meters (about 278.1 acres). It is planned to build a comprehensive logistics dry port integrating container yard, refrigerated warehouse, standard warehouse, parking lot and office area. The construction land area of the first phase is $10,816.54$ square meters, and the building area is 4,2532.7 square meters.

The construction content of the first phase includes 2 refrigerated warehouses (including refrigerator rooms), 2 general warehouses (including on-site offices), auto repair streets, gates and gate offices, transformer substations, water supply adjustment stations, maintenance workshops and tool materials warehouses, containers Storage yards, container washing sites, garbage collection sites, car parking lots, car parking lots, retaining walls, fences and roads.

The two refrigerated warehouses are single-story warehouses with a building outline of $120.48 \mathrm{~m}$ x $43 \mathrm{~m}$, a building area of 7770.9 square meters, a column top structural elevation of $8 \mathrm{~m}$, and an elevated floor of $1.35 \mathrm{~m}$. The 1\# refrigerated warehouse is a high-temperature refrigerated warehouse $\left(0{ }^{\circ} \mathrm{C}\right.$ to $\left.15^{\circ} \mathrm{C}\right)$, and the $2 \#$ refrigerated warehouse is a low-temperature warehouse ($25^{\circ} \mathrm{C}$ to $-22^{\circ} \mathrm{C}$ ).

\section{Comparison of refrigerants}

With the rapid development of the economy, many environmental protection issues have arisen. Therefore, the country has long been on the agenda to strongly advocate the harmonious coexistence of man and nature. For the refrigeration industry, the choice of refrigerant is the first consideration. The refrigerants commonly used in low-temperature refrigeration technology in China mainly include $\mathrm{NH}_{3}, \mathrm{CO}_{2}$ and Freon [1], and their comparisons are shown in Table 1, Figure 1, and Figure 2:

\footnotetext{
* Corresponding author: wangkang@ fhdigz.com
} 
Table 1. Refrigerant comparison table [2]

\begin{tabular}{|c|c|c|c|}
\hline $\begin{array}{l}\text { Refrigerant } \\
\text { Contrastitem }\end{array}$ & $\begin{array}{c}\mathrm{NH}_{3} \text { Two-stage } \\
\text { compression } \\
\text { refrigeration } \\
\end{array}$ & $\begin{array}{c}\mathrm{NH}_{3} / \mathrm{CO}_{2} \\
\text { Refrigerant } \\
\text { cooling } \\
\end{array}$ & Freon refrigeration \\
\hline $\begin{array}{c}\text { Environment } \\
\text { al } \\
\text { Impact Index }\end{array}$ & $\begin{array}{c}\mathrm{ODP}=0, \\
\mathrm{GWP}=0 \\
\text { Environmentall } \\
\mathrm{y} \\
\text { friendly } \\
\text { refrigerant }\end{array}$ & $\begin{array}{c}\mathrm{NH}_{3}: \mathrm{ODP}=0, \\
\mathrm{GWP}=0 \\
\mathrm{CO}_{2}: \mathrm{ODP}=0, \\
\mathrm{GWP}=1 \\
\text { Environmentall } \\
\text { y friendly } \\
\text { refrigerant }\end{array}$ & $\begin{array}{c}\text { R404A:ODP }=0, \\
\text { GWP }=3750 \\
\text { Or } \\
\text { R507A:ODP }=0, \mathrm{GWP}=38 \\
00 \\
\text { Environmentally friendly } \\
\text { refrigerant }\end{array}$ \\
\hline $\begin{array}{l}\text { COP energy } \\
\text { efficiency } \\
\text { value } \\
\mathrm{CT}=35^{\circ} \mathrm{C} \\
\mathrm{ET}=-45^{\circ} \mathrm{C}\end{array}$ & $\begin{array}{c}1.39(2.42) \\
\text { Total low and } \\
\text { medium } \\
\text { cooling } \\
\text { capacity in } \\
\text { parentheses }\end{array}$ & 1.22 & $\begin{array}{l}\text { Related to the type of } \\
\text { refrigerant }\end{array}$ \\
\hline Safety aspect & $\begin{array}{c}\text { Toxic, } \\
\text { flammable } \\
\text { and explosive } \\
\text { Unsafe }\end{array}$ & Safe & Safe \\
\hline $\begin{array}{l}\text { System } \\
\text { ammonia } \\
\text { charge }\end{array}$ & Much & $\begin{array}{c}\text { Less } \\
\text { Can be } \\
\text { concentrated in } \\
\text { the computer } \\
\text { room }\end{array}$ & None \\
\hline Compressor & $\begin{array}{l}\text { Ammonia } \\
\text { compressor }\end{array}$ & $\begin{array}{l}\text { Ammonia } \\
\text { compressor } \\
\text { only }\end{array}$ & Freon compressor \\
\hline $\begin{array}{c}\text { Initial } \\
\text { investment }\end{array}$ & $\begin{array}{l}\text { Assuming } \\
\text { ammonia } \\
\text { system is 1 }\end{array}$ & $1.05 \sim 1.10$ & $\begin{array}{l}\text { Related to specific } \\
\text { configuration }\end{array}$ \\
\hline Running cost & Lower & High & General \\
\hline
\end{tabular}

Note: ODP-potential ozone destruction,

GWP-global warming coefficient value,

CT-condensing temperature,

ET-evaporating temperature.

\section{Comparison of Envitormental Impact Index}

5000

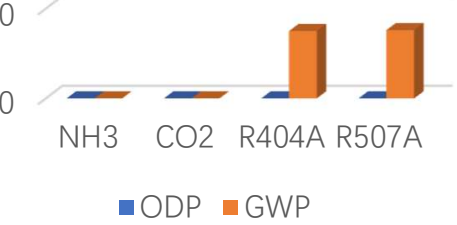

Figure 1. Comparison chart of refrigerant environmental impact index

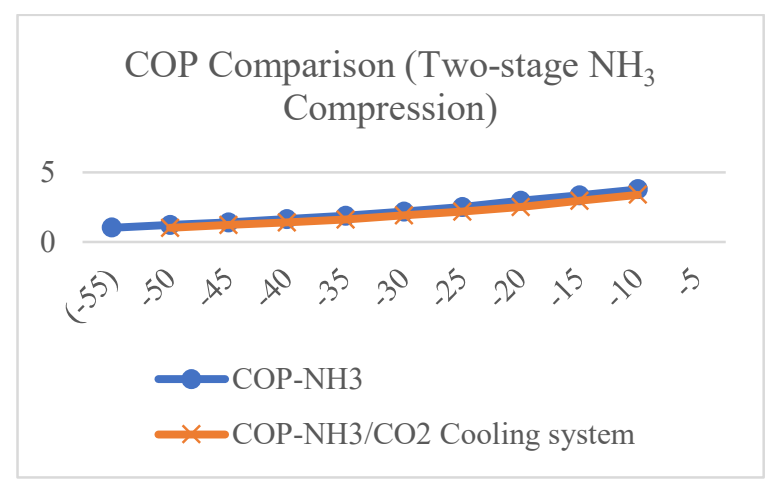

Figure 2. Comparison of COP between two-stage ammonia compression and two-stage ammonia compression $\mathrm{CO}_{2}$ carrier cooling system [3]

In recent years, the cold storage industry has experienced ammonia leakage accidents in Hebei, Shandong, Jilin, and Shanghai. The government and the public are more concerned about the safety of the refrigeration system than ever before. Chinese national standard "Identification of Major Hazardous Sources of Hazardous Chemicals" GB18218-2018[4] stipulates that the critical amount of ammonia is $10 \mathrm{t}$, that is, when the amount of ammonia in the refrigeration system exceeds $10 \mathrm{t}$, the project is classified as a project with major hazardous sources and all supporting facilities and management measures should be set according to the requirements of major hazard sources. With the $\mathrm{NH}_{3} / \mathrm{CO}_{2}$ refrigerant cooling system, the ammonia charge is greatly reduced, and it is concentrated only in the machine room. Its safety is much higher than that of the full ammonia system. At the same time, considering that the Freon listed above is an environmentally friendly refrigerant, its global warming index is still high and will have a certain impact on the environment. From the comprehensive consideration of the social effects of green mountains and green mountains, this project uses $\mathrm{NH}_{3} / \mathrm{CO}_{2}$ as the cooling medium of refrigerant cooling system.

\section{4. $\mathrm{NH}_{3} / \mathrm{CO}_{2}$ refrigerant refrigeration cycle technology}

Schematic diagram of $\mathrm{NH}_{3} / \mathrm{CO}_{2}$ refrigerant cooling system is shown in Figure 3 [3]. The system is mainly composed of a refrigeration system and a carrier cooling system. The two systems are independent and both are closed cycle systems. $\mathrm{NH}_{3}$ refrigeration system consists of ammonia compressor (can be compressed in one stage or two stages, depending on the temperature requirements of the system), oil separator, condenser, ammonia reservoir, throttle valve, ammonia evaporator (condensation evaporator), Ammonia gas-liquid separator and pipeline valves. The $\mathrm{CO}_{2}$ carrier cooling system consists of a $\mathrm{CO}_{2}$ reservoir, a $\mathrm{CO}_{2}$ pump, an evaporator, a $\mathrm{CO}_{2}$ condenser (condensing evaporator), and a pipeline valve. The condensing evaporator is both the evaporator of the $\mathrm{NH}_{3}$ refrigeration system and the condenser of the $\mathrm{CO}_{2}$ carrier cooling system.

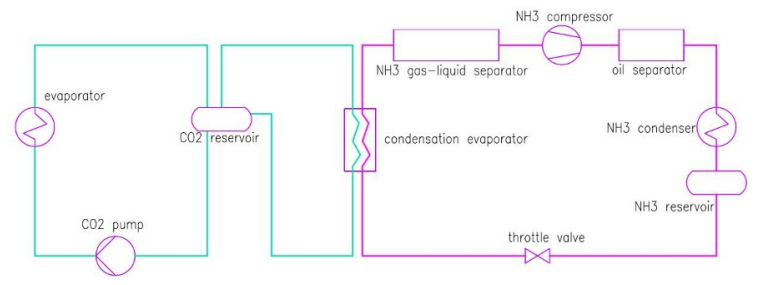

Figure 3. Schematic diagram of $\mathrm{NH}_{3} / \mathrm{CO}_{2}$ refrigerant cooling system

Both the high temperature refrigerated warehouse and the low temperature refrigerated warehouse of this project adopt $\mathrm{NH}_{3} / \mathrm{CO}_{2}$ refrigerant cooling system. The heat load of the envelope structure, the heat load of the cargo, and the heat load of the cooling fan motor are transmitted to the heat by the evaporator in the warehouse $\mathrm{CO}_{2}$ refrigerant, the heat absorbed by the $\mathrm{CO}_{2}$ refrigerant is transferred to the $\mathrm{NH}_{3}$ refrigeration system through the condensation evaporator, and finally the heat is discharged through the condenser of the $\mathrm{NH}_{3}$ refrigeration 
system to complete the entire heat load transfer process. Because the $\mathrm{CO}_{2}$ refrigerant needs to be liquefied with $\mathrm{NH}_{3}$ for heat exchange, two-stage heat exchange temperature difference is required to provide heat exchange capacity. Therefore, the design and optimization of the heat exchanger needs special attention. If the heat exchange temperature difference is large, the system cannot be guaranteed. Higher COP value.

The $\mathrm{CO}_{2}$ refrigerant system does not need to be equipped with a $\mathrm{CO}_{2}$ compressor to achieve oil-free operation, which can avoid the reduction of heat exchange efficiency caused by the refrigerated oil entering the evaporator. The $\mathrm{CO}_{2}$ carrier refrigerant charge in the system is small, and the pipeline size is small. The $\mathrm{NH}_{3}$ refrigerant is only charged in the equipment room system, and its charge is also small, which can increase the safety of the entire system.

\section{Selection of refrigeration equipment}

\subsection{Freezer Refrigerator}

Temperature requirement: $-25^{\circ} \mathrm{C} \sim-22^{\circ} \mathrm{C}$,

Refrigeration method: $\mathrm{NH}_{3} / \mathrm{CO}_{2}$ refrigerant cooling system,

$\mathrm{CO}_{2}$ refrigerant temperature: $-32{ }^{\circ} \mathrm{C}$,

$\mathrm{NH}_{3}$ evaporation temperature: $-35^{\circ} \mathrm{C}$,

$\mathrm{NH}_{3}$ condensation temperature: $+36^{\circ} \mathrm{C}$,

Cooling equipment form: ceiling type stainless steel tube aluminum fan,

Fan defrost method: automatic water defrosts.

The cooling load is shown in Table 2:

Table 2. Refrigeration load table

\begin{tabular}{cccccc}
\hline No. & Room & $\begin{array}{c}\text { Area } \\
\mathrm{m}^{2}\end{array}$ & $\begin{array}{c}\text { Room } \\
\text { temperature } \\
{ }^{\circ} \mathrm{C}\end{array}$ & $\begin{array}{c}\text { Cooling } \\
\text { equipment } \\
\text { load } / \\
\text { room } \\
\mathrm{kW}\end{array}$ & $\begin{array}{c}\text { Total } \\
\text { mechanical } \\
\text { load } \\
\mathrm{kW}\end{array}$ \\
\hline 1 & $\begin{array}{c}1 \# \sim 4 \#, 6 \# \\
\text { frozen } \\
\text { refrigerated } \\
\text { room } \\
5 \#, 7 \# \\
\text { frozen } \\
\text { refrigerated } \\
\text { room }\end{array}$ & 495 & $-25 \sim-22$ & 55 & \\
\hline & 742.5 & $-25 \sim-22$ & 83 & \\
\hline
\end{tabular}

\subsection{Cold storage room}

Temperature requirement: $0^{\circ} \mathrm{C} \sim 15^{\circ} \mathrm{C}$,

Refrigeration method: $\mathrm{NH}_{3} / \mathrm{CO}_{2}$ refrigerant cooling system,

$\mathrm{CO}_{2}$ refrigerant temperature: $-7^{\circ} \mathrm{C}$,

$\mathrm{NH}_{3}$ evaporation temperature: $-10{ }^{\circ} \mathrm{C}$,

$\mathrm{NH}_{3}$ condensation temperature: $+36^{\circ} \mathrm{C}$,

Cooling equipment form: ceiling type stainless steel tube aluminum fan,

Fan defrost method: automatic water defrosts.

The cooling load is shown in Table 3:
Table 3. Refrigerating load of cooling room

\begin{tabular}{|c|c|c|c|c|c|}
\hline $\begin{array}{c}\text { No } \\
\text {. }\end{array}$ & Room & $\begin{array}{c}\text { Area } \\
\mathrm{m}^{2}\end{array}$ & $\begin{array}{c}\text { Room } \\
\text { temperatur } \\
\mathrm{e} \\
{ }^{\circ} \mathrm{C}\end{array}$ & $\begin{array}{c}\text { Cooling } \\
\text { equipmen } \\
\mathrm{t} \\
\text { load / } \\
\text { room } \\
\mathrm{kW}\end{array}$ & $\begin{array}{c}\text { Total } \\
\text { mechanic } \\
\text { al load } \\
\text { kW }\end{array}$ \\
\hline 1 & $\begin{array}{l}\text { 1\# 4\#, } \\
\text { 6\#cold } \\
\text { storage }\end{array}$ & 495 & $0 \sim 15$ & 166 & \multirow[b]{2}{*}{850} \\
\hline 2 & $\begin{array}{l}5 \#, 7 \# \text { high } \\
\text { temperatur } \\
\text { e storage } \\
\text { room }\end{array}$ & $\begin{array}{c}742 . \\
5\end{array}$ & $0 \sim 15$ & 240 & \\
\hline
\end{tabular}

\subsection{Selection of refrigeration system equipment}

\subsubsection{Freezer refrigerated room}

Three sets of $\mathrm{NH}_{3} / \mathrm{CO}_{2}$ unit modules are selected for the low-temperature warehouse refrigeration system, with a total cooling capacity of $110 \times 3=$ $330 \mathrm{~kW}$, which meets the requirements for use. This unit module includes ammonia compressor, condensing evaporator, high-pressure reservoir and corresponding pipelines, valves, control cabinets, etc. $\mathrm{CO}_{2}$ air cooler: ceiling-mounted stainless-steel tube aluminum air cooler is adopted, and automatic water flushing is adopted.

\subsubsection{Cold storage room}

The high-temperature warehouse refrigeration system uses two sets of $\mathrm{NH}_{3} / \mathrm{CO}_{2}$ unit modules, with a total cooling capacity of $428 \times 2=856 \mathrm{~kW}$, which meets the requirements for use. This unit module includes ammonia compressor, condensing evaporator, high-pressure reservoir and corresponding pipelines, valves, control cabinets, etc.

$\mathrm{CO}_{2}$ air cooler: ceiling-mounted stainless-steel tube aluminum air cooler is adopted, and automatic water flushing is adopted.

\subsection{Frost water system}

Four cold air blowers are combined with one defrost pipeline. 3 sets of frosting vertical self-priming pumps are used ( 2 use and 1 standby), with a single flow of $25 \mathrm{~m}^{3} / \mathrm{h}$ and a head of $32 \mathrm{~m}$. The frost supply and return water pipes in the refrigerating room are all made of polyurethane insulation, and the outer layer of insulation is made of $0.35 \mathrm{~mm}$ thick color steel plate. The pipes of the frosting water system are all welded steel pipes.

\section{Automatic control system solution}

The refrigeration system of this project realizes automatic control. Its control system monitors the relevant refrigerating room temperature, return air temperature, return air pressure, the start and stop of the cold air blower, the alarm of personnel being shut down, etc., and meets 
the various technological requirements of the refrigeration process.

In terms of safety, corresponding gas concentration detection and alarm systems are set up to ensure the safe operation of refrigeration system devices and prevent accidents. Ammonia only circulates in the refrigerating machine room, and an ammonia gas concentration detection alarm system is set in the refrigerating machine room [5]. When the ammonia concentration in the air exceeds the standard, an alarm signal will be automatically issued, and the accident exhaust fan will be automatically activated at the same time. Considering the safety accidents such as $\mathrm{CO}_{2}$ leakage that may cause suffocation of personnel, $\mathrm{CO}_{2}$ concentration detectors are installed at locations that may release carbon dioxide, such as $\mathrm{CO}_{2}$ delivery pumps, valves, flanges, and airconditioning outlets. Audible and visual alarms are issued when the concentration exceeds the standard. In addition, this project is equipped with multiple portable ammonia concentration detectors and $\mathrm{CO}_{2}$ concentration detectors, which is convenient for improving the safety of workers. The control system of this project automatically starts and stops according to changes in external conditions or the user's needs, and automatically adjusts the work of the refrigeration system equipment, which not only saves operators, simplifies management, but also improves the economical operation of the refrigeration equipment. Reduce energy consumption. At the same time, the refrigerator realizes automatic control to keep the temperature of the warehouse stable to improve the quality of commodity storage.

\section{Conclusions}

$\mathrm{NH}_{3} / \mathrm{CO}_{2}$ refrigerant cooling system has its advantages and disadvantages: the two working fluids in the system are environmentally friendly refrigerants, the potential for ozone destruction is 0 , and the impact on global warming is minimal. Environmental pollution issues have good economics; the ammonia charge is small, which can reduce the risk of major hazardous sources; the energy efficiency is slightly lower than the ammonia two-stage compression; the critical pressure of $\mathrm{CO}_{2}$ is high, and the requirements for the equipment are also high.

The comprehensive logistics cold chain project is developing rapidly, and the choice of refrigeration system is very important. It is necessary to choose the appropriate system after weighing various factors in accordance with local laws and regulations and storage production and use requirements.

\section{References}

1. Lv Jing, Wang Weifeng, Zhou Chuanyu. Analysis of thermodynamic performance in $\mathrm{CO} 2$ cascade refrigeration cycle[J]. Cryogenics,2008,164(4) 38-41.

2. Shi min, Jia lei. CO2 refrigeration technology[J]. Refrigeration and Air Conditioning,2007,12(6) 1-5.

3. Tian Yafen, Zhao Zhaorui, Xing Ziwen. Study on Application Scope for CO2 Cascade Refrigeration
System and CO2 Secondary Refrigerant System[J]. Journal of Refrigeration,2016,37(2)22-29.

4. China National Standardization Management Committee. Identification of major hazard installations for hazardous chemicals: GB 182182018 [S].

5. Lu yaoqing. Practical heating and air conditioning design hand book [M]. (Second Edition). Beijing, China Construction Industry Press,2008. 